\title{
Statistical Analysis and Evaluation of Heavy Metal Ions in Soil Environment
}

\author{
Min Tang, Jianping Hou \\ Environmental Monitoring Station, Chongqing, China \\ Email: tengzi12280741@163.com
}

Received 28 April 2016; accepted 21 May 2016; published 26 May 2016

Copyright (C) 2016 by authors and OALib.

This work is licensed under the Creative Commons Attribution International License (CC BY). http://creativecommons.org/licenses/by/4.0/

C) (i) Open Access

\begin{abstract}
The paper comprehensively analyzes and evaluates the urban grid soil and rural soil quality and pollution characteristics through methods of single factor index and Nemero comprehensive pollution index on the physical and chemical nature of soil, the element pollutants, organic pollutants and other pollutants. The contents of soil pollutants in rural and urban areas showed that the overall soil quality is good and advice on how to improve soil quality in the region is put forward.
\end{abstract}

\section{Keywords}

Soil Environment, Heavy Metals, Statistical Analysis, Single Factor Index Method and Nemerow
Comprehensive Pollution Index Method

Subject Areas: Environmental Sciences

\section{Introduction}

With the rapid development of industry and agriculture, the unreasonable use of pesticides and fertilizers, longterm sewage irrigation, as well as urban and industrial pollution and other factors since 1930s, through different ways, a great number of pollutants entered into the soil environment, did damage to the soil structure, destroyed the soil function [1], and caused quality deterioration of soil ecological environment, making soil pollution a great threat to agricultural product quality safety across China and even the global [2]. The composition, structure, function, characteristics and the special status and role played in the environment ecosystem in environmental ecosystem of soil make the soil pollution more complicated than the air and water pollution.

Soil pollutants can be roughly divided into two kinds: inorganic pollutants and organic pollutants [3]. Inorganic pollutants mainly include acid, alkali, heavy metals, salts, compound of radioactive elements Cs and Sr, compound of As, Se and F etc. Organic pollutants mainly include organic pesticides, phenols, cyanide, petroleum, synthetic detergent, benzopyrene and harmful micro-creature produced by the city sewage, sludge and manure etc. In order to know about the current situation of soil environmental quality in $\mathrm{X}$ area of China, improve the 
ability to monitor soil pollution, evaluate the risk of soil pollution, confirm the soil environmental safety level, and establish the supervision and management system for soil environmental quality, an investigation on soil environmental quality was carried out in 2014. The investigation and monitoring protect and reasonably utilize land resources, as well as offer scientific and effective basic data to improve the quality of soil environment.

\section{Survey Method}

Grid distribution is used in urban soil, which means that $1 \mathrm{~km} \times 1 \mathrm{~km}$ size square grid is drawn in administrative map with corresponding proportion, 1 monitoring point lying in each grid. According to the landscape, distribution of land use types, soil types and other factors in Northern Yangtze River area, the number of points is obtained by the formula that land use area/grid size $=$ number of sample points. After optimization, points number of urban soil survey is ultimately determined as 62 . The rural scope of the soil investigation involves the 7 villages of Wubao town and each village has 1 monitoring point, 7 monitoring points in total.

\section{Evaluation Index}

The evaluation on soil quality is mainly based on Soil environmental quality standard (GB15618-1995) [4], which is divided into three major categories. Class I is mainly applicable to natural reserves approved by the state (except reserves with the original background of high heavy metal concentrations), the centralized drinking water source, tea garden, and pasture and soil in other protected areas; soil quality maintains the natural background level. Class II is mainly suitable for general farmland, vegetable lands, tea gardens, orchards, pasture and other soil; soil quality basically does not do harm to the plant and the environment nor causes pollution. Class III is mainly used in forest land and farmland such as soil with high background value and mineral those have large deal of pollutants (except the vegetable land) ; soil quality basically does not do harm to the plant and the environment nor causes pollution. The detection of soil generally focuses on detecting their physicochemical properties: $\mathrm{pH}$, full Nitrogen, full Phosphorus and full Kalium and the organics; elements: Arsenic, Cadmium, Cobalt, Chromium, Copper, Fluoride, Mercury, Manganese, Nickel, Lead, Selenium, Vanadium, Zinc; organic pollutants: organochlorine pesticides (Six Six Six, DDT) and other major categories. Soil is often contaminated by a variety of heavy metals. Therefore methods of single factor index [5] and Nemero comprehensive pollution index [6] [7] are often used for comprehensive evaluation on soil pollution.

\subsection{Single Factor Pollutant Index}

$\mathrm{P}_{\mathrm{i}}$ reflects the extent of pollution. Its values less than 1 means no pollution while that greater than 1 means pollution. It can be expressed as follows.

$$
P_{i}=C_{i} / S_{i}
$$

where $P_{i}$ is the single pollution index of pollutant $i$ in the soil; $C_{i}$ is the measured concentration of pollutant $i$ in the soil of surveyed locations; $S_{i}$ is standard referential value for the evaluation of pollutant $i$.

\subsection{Nemero Comprehensive Pollution Index}

Nemero comprehensive pollution index are often used for comprehensive evaluation on soil pollution and the formulation is as below:

$$
\begin{aligned}
& P_{N}=\left\{\left[\left(P_{\text {mean }}\right)+\left(P_{\text {max }}^{2}\right)\right] / 2\right\}^{1 / 2} \\
& P_{N}=\left\{\left[\left(P_{\text {mean }}\right)+\left(P_{\text {max }}^{2}\right)\right] / 2\right\}^{1 / 2}
\end{aligned}
$$

where $P_{N}$ is the Nemero comprehensive pollution index; $P_{\text {mean }}$ is the average single pollution index; $P_{\text {mean }}^{2}$ is the maximum single pollution index.

Nemero index reflects the effect of the pollutants on the soil [6] [7], while highlighting the impact of highconcentration pollutants on the soil environment quality. Pollution levels can be divided according to the Nemero pollution index. Soil pollution evaluation criteria for Nemero index see Table 1. 
Table 1. Nemero pollution index soil evaluation criteria.

\begin{tabular}{ccc}
\hline Grade division & Single pollution index & Class of pollution \\
\hline I & $\mathrm{PN} \leq 0.7$ & Clean (SAFE) \\
II & $0.7<\mathrm{PN} \leq 1$ & Relatively clean (alert limit) \\
III & $1<\mathrm{PN} \leq 2$ & mild concentration \\
IV & $2<\mathrm{PN} \leq 3$ & middle level pollution \\
V & $\mathrm{PN}>3$ & heavy pollution \\
\hline
\end{tabular}

\section{Results and Discussions}

There are 7 sampling rural fields for the survey, and the monitoring projects include 20 items: $\mathrm{pH}$, full Nitrogen, full Phosphorus and full Kalium and the organics; elements: Arsenic, Cadmium, Cobalt, Chromium, Copper, Fluoride, Mercury, Manganese, Nickel, Lead, Selenium, Vanadium, and Zinc. The monitoring results of physicochemical properties, elemental pollutants and organics are shown in Tables 2-4, respectively.

Basic situation of soil fertility: the material composition, structure status and the natural conditions determine the level of soil fertility, which affects growth of plant and is the material basis for the crop yields [8]. From the results of the physicochemical property in Table 7, the $\mathrm{pH}$ of rural sampling points varies from 6.9 to 8.0 while the appropriate growth $\mathrm{pH}$ environment for general crops is nearly neutral. Thus, the rural soil $\mathrm{pH}$ is moderate.

According to the dry soil fertility grading standard (see Table 5) of Environmental quality standard of national green food places of origin (NY/T391-2000) [9], among seven surveyed villages, whose soil organic contents vary from 9.2 to $14.2 \mathrm{~g} / \mathrm{kg}$, the highest is village $\mathrm{C}$, and the lowest is village $\mathrm{F}$. The content of organics reaching class II of accounts for $71.4 \%$, class III $28.6 \%$, which shows that the majority of soil organics in the seven villages reaches class II (good level). The monitoring results of soil full Nitrogen, full Potassium and full Phosphorus show that the soil fertility levels of the seven villages are all proved to be class III (relatively bad level), indicating the insufficient contents of $\mathrm{N}, \mathrm{P}$ and $\mathrm{K}$ in soil.

The content and distribution of pollutants : The monitoring result of element pollutants in Table 3 shows that there is no Arsenic, Mercury and Cadmium, Selenium in the seven villages; the content of Fluoride is 189 - 452 $\mathrm{mg} / \mathrm{kg}$, the average value is $318 \mathrm{mg} / \mathrm{kg}$, and village A has the highest content of it; the content of Chromium is $58-198 \mathrm{mg} / \mathrm{kg}$, the average value is $107 \mathrm{mg} / \mathrm{kg}$, and village $\mathrm{G}$ has the highest content of it; the content of Copper is $15-43 \mathrm{mg} / \mathrm{kg}$, the average value is $32 \mathrm{mg} / \mathrm{kg}$, and village A has the highest content of it; the content of Manganese is $505-7306 \mathrm{mg} / \mathrm{kg}$, the average value is $1988 \mathrm{mg} / \mathrm{kg}$, and village F has the highest content of it; the content of Zinc is 24 - $99 \mathrm{mg} / \mathrm{kg}$, the average value is $58 \mathrm{mg} / \mathrm{kg}$, and village B has the highest content of it; the content of Nickel is $33 \mathrm{mg} / \mathrm{kg}$, it's sampled in village B and none of it were detected in the other six villages; the content of Cobalt is $0-1195 \mathrm{mg} / \mathrm{kg}$, and village F has the highest content of it; the content of Lead is 0 - 24 $\mathrm{mg} / \mathrm{kg}$, and village A has the highest content of it. From the organochlorine pesticide monitoring result in Table 4, organochlorine pesticides of Six Six Six and DDT were not detected in any of the seven villages. In all of the monitoring results, Cadmium, Mercury, Arsenic, Copper, Lead, Chromium, Zinc, Nickel and organochlorine pesticides all meet class II. Five elements of Fluoride, Manganese, Cobalt, Selenium and Vanadium are not required in class II. And those that are detected high content of elemental monitoring factors are village F, A and B.

Urban grid soil sampling points are distributed across the whole are, a total of 62 points, and the monitoring projects include 14 items: pH, Arsenic, Cadmium, Cobalt, Chromium, Copper, Fluoride, Mercury, Manganese, Nickel, Lead, Selenium, Vanadium, and Zinc. The detailed monitoring result is shown in Tables 5-7.

Statistics of $\mathrm{pH}$ monitoring: Among 62 urban grid soil point locations, $\mathrm{pH}$ monitoring result is in the range of $4.72-8.40$, the lowest is in the entry into 412 Park, the highest point is 708 . There are 9 points with value of $\mathrm{pH}$ less than 6.5 accounting for $14.5 \%$ of the total grid number. The number of $\mathrm{pH}$ value ranging from the $6.5-7.5$ is 14 accounting for $22.6 \%$ of the total grid number. The number of $\mathrm{pH}$ value greater than 7.5 is 39 accounting for $62.9 \%$ of the total grid number. The result shows that the $\mathrm{pH}$ in this area of soil is alkalescent (Figure 1 ).

Pollution index evaluation [10]: according to the monitoring results of heavy metal pollutants in soil, single factor index and comprehensive pollution index are calculated respectively and the detailed results are shown in Table 8. 
Table 2. List of results of physical and chemical properties of rural areas.

\begin{tabular}{cccccc}
\hline \multirow{2}{*}{ Sampling point } & \multicolumn{5}{c}{ Projects and results } \\
\cline { 2 - 6 } & $\mathrm{pH}$ & Total nitrogen (\%) & Total phosphorus $(\mathrm{mg} / \mathrm{Kg})$ & Total potassium $(\mathrm{mg} / \mathrm{Kg})$ & organic matter $(\mathrm{g} / \mathrm{Kg})$ \\
\hline A & 7.62 & 0.004 & ND & 25764 & 13.4 \\
B & 7.83 & 0.002 & ND & 27702 & 9.9 \\
C & 7.68 & 0.006 & ND & 19854 & 14.2 \\
D & 7.25 & 0.005 & ND & 29687 & 13.5 \\
E & 7.84 & 0.009 & ND & 25103 & 12.9 \\
F & 8.02 & ND & ND & 20530 & 9.2 \\
G & 6.93 & 0.003 & ND & 30605 & 11.5 \\
\hline
\end{tabular}

Remarks: ND: Not detected.

Table 3. List of monitoring results of soil elements in rural areas (unit $\mathrm{mg} / \mathrm{Kg}$ ).

\begin{tabular}{|c|c|c|c|c|c|c|c|c|c|c|c|c|}
\hline \multirow{2}{*}{ Sampling point } & \multicolumn{12}{|c|}{ Projects and results } \\
\hline & Fluoride & As & Cd & Co & $\mathrm{Cr}$ & $\mathbf{C u}$ & Hg & Mn & $\mathbf{N i}$ & $\mathbf{P b}$ & Se & Zn \\
\hline A & 452 & ND & ND & ND & 58 & 43 & ND & 572 & ND & 24 & ND & 83 \\
\hline B & 361 & ND & ND & ND & 84 & 29 & ND & 560 & 33 & 20 & ND & 99 \\
\hline $\mathrm{C}$ & 204 & ND & ND & ND & 74 & 15 & ND & 505 & ND & 20 & ND & 46 \\
\hline $\mathrm{D}$ & 344 & ND & ND & 195 & 88 & 33 & ND & 880 & ND & ND & ND & 69 \\
\hline $\mathrm{E}$ & 382 & ND & ND & 460 & 104 & 35 & ND & 1551 & ND & ND & ND & 56 \\
\hline $\mathrm{F}$ & 189 & ND & ND & 521 & 140 & 27 & ND & 2544 & ND & ND & ND & 24 \\
\hline G & 293 & ND & ND & 1195 & 198 & 42 & ND & 7306 & ND & ND & ND & 26 \\
\hline
\end{tabular}

Remarks: ND: Not detected.

Table 4. A list of results of the monitoring results of soil organic chlorine pesticides in rural areas (unit: $\mathrm{mg} / \mathrm{Kg}$ ).

\begin{tabular}{|c|c|c|c|c|c|c|c|c|}
\hline \multirow{2}{*}{$\begin{array}{l}\text { Sampling } \\
\text { point }\end{array}$} & \multicolumn{8}{|c|}{ A list of results of the monitoring results of soil organic chlorine pesticides in rural areas (unit: $\mathrm{mg} / \mathrm{Kg}$ ).Projects and results } \\
\hline & $\begin{array}{c}\alpha \text {-benzene } \\
\text { hexachloride }\end{array}$ & $\begin{array}{c}\beta \text {-benzene } \\
\text { hexachloride }\end{array}$ & $\begin{array}{c}\gamma \text {-benzene } \\
\text { hexachloride }\end{array}$ & $\begin{array}{c}\delta \text {-benzene } \\
\text { hexachloride }\end{array}$ & p,p'-DDD & p,p'-DDE & p,p'-DDT & o,p'-DDT \\
\hline A & ND & ND & ND & ND & ND & ND & ND & ND \\
\hline B & ND & ND & ND & ND & ND & ND & ND & ND \\
\hline C & ND & ND & ND & ND & ND & ND & ND & ND \\
\hline D & ND & ND & ND & ND & ND & ND & ND & ND \\
\hline E & ND & ND & ND & ND & ND & ND & ND & ND \\
\hline F & ND & ND & ND & ND & ND & ND & ND & ND \\
\hline G & ND & ND & ND & ND & ND & ND & ND & ND \\
\hline
\end{tabular}

Remarks: ND: Not detected. 
Table 5. List of monitoring results of soil elements in urban areas $(\mathrm{pH}<6.5)$ (unit: $\mathrm{mg} / \mathrm{Kg}$ ).

\begin{tabular}{cccccccccccccc}
\hline Grid name & $\mathrm{pH}$ & $\mathrm{V}$ & $\mathrm{Cr}$ & $\mathrm{Mn}$ & $\mathrm{Co}$ & $\mathrm{Ni}$ & $\mathrm{Cu}$ & $\mathrm{Zn}$ & $\mathrm{As}$ & $\mathrm{Se}$ & $\mathrm{Cd}$ & $\mathrm{Hg}$ & $\mathrm{Pb}$ \\
\hline 005 & 5.27 & 227 & 199 & 32,229 & 1866 & $\mathrm{ND}$ & 95 & 22 & $\mathrm{ND}$ & $\mathrm{ND}$ & $\mathrm{ND}$ & $\mathrm{ND}$ & 165 \\
509 & 6.07 & 98 & 76 & 257 & $\mathrm{ND}$ & $\mathrm{ND}$ & 27 & 55 & 17 & $\mathrm{ND}$ & $\mathrm{ND}$ & $\mathrm{ND}$ & 14 \\
306 & 6.33 & 370 & 77 & 6580 & $\mathrm{ND}$ & 67 & 37 & 68 & 23 & $\mathrm{ND}$ & $\mathrm{ND}$ & $\mathrm{ND}$ & 36 \\
004 & 5.98 & 102 & 81 & 682 & $\mathrm{ND}$ & 30 & 42 & 104 & 17 & $\mathrm{ND}$ & $\mathrm{ND}$ & $\mathrm{ND}$ & 21 \\
511 & 5.18 & 81 & 64 & 383 & $\mathrm{ND}$ & $\mathrm{ND}$ & 28 & 52 & $\mathrm{ND}$ & $\mathrm{ND}$ & $\mathrm{ND}$ & $\mathrm{ND}$ & 26 \\
003 & 5.82 & 77 & 72 & 430 & $\mathrm{ND}$ & 51 & 29 & 68 & 11 & $\mathrm{ND}$ & $\mathrm{ND}$ & $\mathrm{ND}$ & 18 \\
105 & 6.32 & 91 & 108 & 601 & 198 & $\mathrm{ND}$ & 39 & 77 & $\mathrm{ND}$ & $\mathrm{ND}$ & $\mathrm{ND}$ & $\mathrm{ND}$ & 25 \\
412 & 4.72 & 73 & 72 & 459 & 110 & $\mathrm{ND}$ & 18 & 38 & 9 & $\mathrm{ND}$ & $\mathrm{ND}$ & $\mathrm{ND}$ & 13 \\
304 & 6.26 & 97 & 69 & 528 & $\mathrm{ND}$ & $\mathrm{ND}$ & 31 & 78 & $\mathrm{ND}$ & $\mathrm{ND}$ & $\mathrm{ND}$ & $\mathrm{ND}$ & 31 \\
Standard limit $(\leq)$ & $/$ & $/$ & 150 & $/$ & $/$ & 40 & 50 & 200 & 40 & $/$ & 0.30 & 0.30 & 250 \\
\hline
\end{tabular}

Remarks: ND: Not detected.

Table 6. List of monitoring results of soil elements in urban areas $(\mathrm{pH}>7.5)(\mathrm{unit}: \mathrm{mg} / \mathrm{Kg})$.

\begin{tabular}{|c|c|c|c|c|c|c|c|c|c|c|c|c|c|}
\hline Grid name & $\mathrm{pH}$ & V & $\mathrm{Cr}$ & Mn & Co & $\mathrm{Ni}$ & $\mathrm{Cu}$ & $\mathrm{Zn}$ & As & Se & $\mathrm{Cd}$ & $\mathrm{Hg}$ & $\mathrm{Pb}$ \\
\hline 708 & 8.40 & 114 & 77 & 673 & ND & 29 & 21 & 82 & ND & ND & ND & ND & 24 \\
\hline 708 & 8.40 & 133 & 83 & 742 & ND & 29 & 45 & 107 & ND & ND & ND & ND & 35 \\
\hline 601 & 7.72 & 98 & 53 & 551 & ND & 35 & 37 & 70 & 16 & ND & ND & ND & 18 \\
\hline 707 & 8.01 & 76 & 77 & 569 & ND & ND & 41 & 86 & ND & ND & ND & ND & 24 \\
\hline 801 & 8.12 & 99 & 87 & 539 & ND & 31 & 39 & 83 & 12 & ND & ND & ND & ND \\
\hline 701 & 7.55 & 94 & 127 & 668 & ND & 32 & 54 & 169 & 15 & ND & ND & ND & 47 \\
\hline 603 & 7.72 & 105 & 77 & 846 & ND & 43 & 32 & 110 & ND & ND & ND & ND & 23 \\
\hline 706 & 7.85 & 87 & 72 & 613 & ND & 35 & 45 & 86 & 15 & ND & ND & ND & 26 \\
\hline 805 & 7.68 & 108 & 74 & 555 & ND & ND & 33 & 93 & 10 & ND & ND & ND & 18 \\
\hline 308 & 8.06 & 101 & 69 & 614 & ND & 32 & 29 & 79 & 12 & ND & ND & ND & 16 \\
\hline 211 & 7.93 & 89 & 54 & 448 & ND & ND & 22 & 61 & 9 & ND & ND & ND & 13 \\
\hline 107 & 7.82 & 113 & 104 & 758 & ND & ND & 42 & 98 & 16 & ND & ND & ND & 21 \\
\hline 712 & 7.94 & 91 & 86 & 665 & ND & 36 & 67 & 88 & ND & ND & ND & ND & 26 \\
\hline 413 & 8.04 & 106 & 76 & 740 & ND & 33 & 22 & 74 & 11 & ND & ND & ND & 23 \\
\hline 605 & 7.77 & 99 & 43 & 578 & ND & 36 & ND & 73 & ND & ND & ND & ND & 22 \\
\hline 803 & 8.33 & 102 & 77 & 589 & ND & 40 & 55 & 89 & ND & ND & ND & ND & 31 \\
\hline 607 & 7.86 & 131 & 65 & 541 & ND & ND & 82 & 321 & 23 & ND & ND & ND & 40 \\
\hline 709 & 7.88 & 113 & 58 & 570 & ND & 42 & 32 & 90 & 14 & 5.5 & ND & ND & 31 \\
\hline 406 & 7.78 & 100 & 60 & 570 & ND & 52 & 37 & 84 & ND & ND & ND & ND & 19 \\
\hline 508 & 7.82 & 74 & 51 & 87 & ND & ND & ND & 37 & 17 & ND & ND & ND & 16 \\
\hline 309 & 8.12 & 91 & 64 & 581 & ND & 28 & 41 & 84 & ND & ND & ND & ND & 24 \\
\hline 408 & 7.68 & 97 & 79 & 881 & ND & 42 & 98 & 182 & ND & ND & ND & ND & 83 \\
\hline 606 & 7.60 & 104 & 73 & 557 & ND & 36 & 23 & 87 & 14 & ND & ND & ND & 22 \\
\hline
\end{tabular}




\section{Continued}

\begin{tabular}{|c|c|c|c|c|c|c|c|c|c|c|c|c|c|}
\hline 502 & 7.63 & 86 & 85 & 547 & ND & 48 & 34 & 69 & ND & ND & ND & ND & 24 \\
\hline 612 & 7.56 & 108 & 41 & 395 & ND & 34 & 27 & 64 & ND & ND & ND & ND & 17 \\
\hline 409 & 7.74 & 90 & 102 & 594 & ND & ND & 24 & 97 & 12 & ND & ND & ND & 20 \\
\hline 705 & 7.78 & 88 & 67 & 478 & ND & ND & 24 & 82 & ND & ND & ND & ND & 30 \\
\hline 802 & 7.67 & 87 & 70 & 722 & ND & 45 & 36 & 77 & ND & ND & ND & ND & 30 \\
\hline 202 & 7.84 & 115 & 52 & 510 & ND & ND & 39 & 76 & ND & ND & ND & ND & 22 \\
\hline 204 & 8.25 & 111 & 73 & 650 & ND & 32 & 31 & 81 & 10 & ND & ND & ND & 13 \\
\hline 106 & 7.90 & 87 & 52 & 639 & ND & ND & 35 & 68 & 14 & ND & ND & ND & 18 \\
\hline 804 & 8.08 & 108 & 81 & 677 & ND & 38 & 44 & 85 & ND & ND & ND & ND & 27 \\
\hline 307 & 8.18 & 95 & 60 & 623 & ND & 31 & 17 & 65 & ND & ND & ND & ND & 15 \\
\hline 510 & 7.83 & 110 & 98 & 1150 & 373 & ND & 32 & 67 & ND & ND & ND & ND & ND \\
\hline 103 & 8.32 & 128 & 114 & 1549 & 571 & ND & 32 & 60 & ND & ND & ND & ND & ND \\
\hline 104 & 7.79 & 193 & 216 & 2887 & 1050 & ND & 54 & 62 & ND & ND & ND & ND & ND \\
\hline 109 & 7.70 & 154 & 243 & 5659 & 1201 & ND & 65 & 42 & ND & ND & ND & ND & ND \\
\hline 108 & 7.81 & 128 & 217 & 5221 & 1182 & ND & 52 & 25 & ND & ND & ND & ND & ND \\
\hline 506 & 7.84 & 229 & 309 & 7554 & 1638 & ND & 223 & 216 & 19 & ND & ND & ND & ND \\
\hline 110 & 7.66 & 169 & 258 & 13,001 & 1558 & ND & 56 & 22 & ND & ND & ND & ND & ND \\
\hline Standard limit $(\leq)$ & 1 & 1 & 250 & 1 & 1 & 60 & 100 & 300 & 25 & 1 & 0.60 & 1.0 & 350 \\
\hline
\end{tabular}

Remarks: ND: Not detected.

Table 7. List of monitoring results of soil elements in urban areas $(\mathrm{pH}=6.5$ - 7.5) (unit: $\mathrm{mg} / \mathrm{Kg})$.

\begin{tabular}{|c|c|c|c|c|c|c|c|c|c|c|c|c|c|}
\hline Grid name & $\mathrm{pH}$ & $\mathrm{V}$ & $\mathrm{Cr}$ & $\mathrm{Mn}$ & Co & $\mathrm{Ni}$ & $\mathrm{Cu}$ & $\mathrm{Zn}$ & As & Se & Cd & $\mathrm{Hg}$ & $\mathrm{Pb}$ \\
\hline 609 & 7.02 & 285 & 492 & 31,354 & 2676 & ND & 81 & 27 & ND & ND & ND & ND & 86 \\
\hline 410 & 7.44 & 161 & 224 & 6435 & 1977 & ND & 93 & 95 & ND & ND & ND & ND & ND \\
\hline 703 & 7.41 & 78 & 152 & 579 & ND & 37 & 84 & 286 & ND & ND & ND & ND & 86 \\
\hline 310 & 6.86 & 84 & 64 & 133 & ND & 41 & 18 & 33 & 11 & ND & ND & ND & 20 \\
\hline 402 & 7.20 & 110 & 89 & 580 & ND & ND & 33 & 85 & ND & ND & ND & ND & 17 \\
\hline 702 & 7.46 & 114 & 77 & 554 & ND & 50 & 45 & 85 & ND & ND & ND & ND & 21 \\
\hline 711 & 7.32 & 100 & 88 & 682 & ND & ND & 50 & 76 & 12 & ND & ND & ND & 25 \\
\hline 312 & 6.95 & 101 & 59 & 520 & ND & 31 & 40 & 74 & ND & ND & ND & ND & 22 \\
\hline 203 & 7.20 & 75 & 46 & 519 & ND & ND & ND & 72 & ND & ND & ND & ND & 55 \\
\hline 710 & 7.29 & 100 & 72 & 551 & ND & 39 & 44 & 93 & ND & ND & ND & ND & 24 \\
\hline 206 & 7.12 & 117 & 82 & 574 & ND & 31 & 39 & 94 & ND & ND & ND & ND & 30 \\
\hline 208 & 7.26 & 102 & 75 & 452 & ND & ND & 29 & 78 & 10 & ND & ND & ND & 26 \\
\hline 313 & 7.15 & 89 & 50 & 400 & ND & ND & 30 & 55 & 16 & ND & ND & ND & 22 \\
\hline 207 & 7.22 & 93 & 89 & 536 & ND & ND & 28 & 99 & 15 & ND & ND & ND & 21 \\
\hline Standard limit $(\leq)$ & 1 & I & 200 & I & I & 50 & 100 & 250 & 30 & 1 & 0.30 & 0.50 & 300 \\
\hline
\end{tabular}

Remarks: ND: Not detected. 


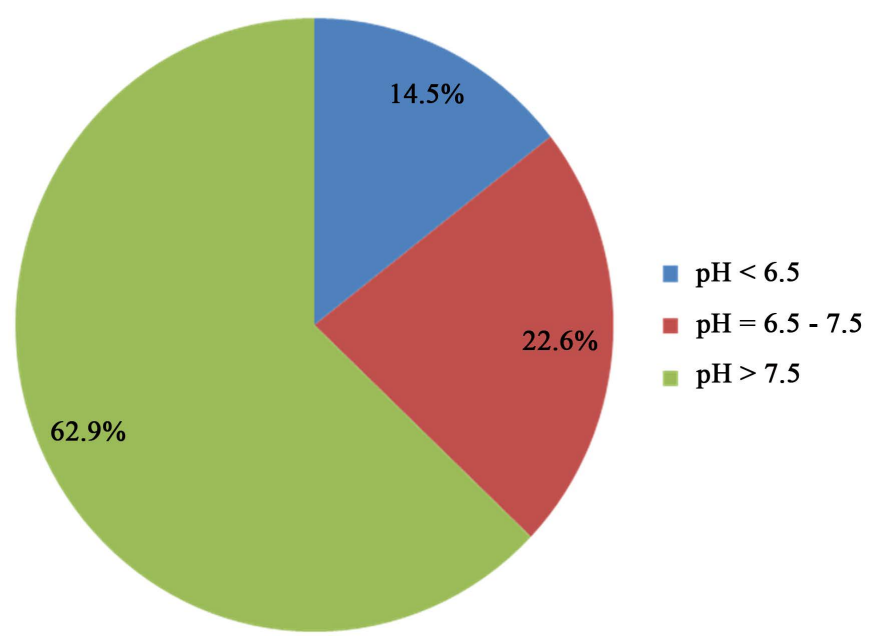

Figure 1. The $\mathrm{pH}$ range distribution of the grid soil.

Table 8. Heavy metal pollution index of soil.

\begin{tabular}{|c|c|c|c|c|c|c|c|c|}
\hline \multirow{2}{*}{ Area } & \multirow{2}{*}{$\begin{array}{l}\text { Sample } \\
\text { number }\end{array}$} & \multicolumn{6}{|c|}{$\mathrm{Pi}$} & \multirow{2}{*}{$\begin{array}{l}\text { Comprehensive } \\
\text { pollution index }\end{array}$} \\
\hline & & $\mathrm{Cr}$ & $\mathrm{Zn}$ & $\mathrm{Ni}$ & As & $\mathrm{Pb}$ & $\mathrm{Cu}$ & \\
\hline City Proper & 62 & 0.50 & 0.34 & 0.38 & 0.20 & 0.09 & 0.21 & 0.41 \\
\hline Countryside & 7 & 0.43 & 0.19 & 0.08 & / & 0.03 & 0.32 & 0.24 \\
\hline
\end{tabular}

From Table 8, it can be seen that the comprehensive pollution index of the rural soil and urban grid soil is less than 0.7, which means safe and clean. The single factor pollution index indicates the greatest single factor pollution index of $\mathrm{Cr}$ in Northern Yangtze River area, which shows that the main pollution factor in this area is Cr.

\section{Conclusions}

From the above investigations, the followings are concluded:

1) The contains of heavy metals and organ chlorine pesticides in the soil of the Northern Yangtze River area are low, abundant in the organics, N, P, K are obviously insufficient but in some areas the organic content is low and organic fertilizers should be added.

2) The total content of heavy metals in urban soils of Northern Yangtze River area is not very high, and the soil environment quality is good. In terms of the average pollutant index level of heavy metals, there is no pollution, but the heavy metal content in some regions is high, which leads to relatively high potential hazard.

\section{References}

[1] Nogueira, T.A.R., Franco, A., He, Z., et al. (2013) Short-Term Usage of Sewage Sludge as Organic Fertilizer to Sugarcane in a Tropical Soil Bears Little Threat of Heavy Metal Contamination. Journal of Environmental Management, 114, 168-177. http://dx.doi.org/10.1016/j.jenvman.2012.09.012

[2] Ganyuan (2009) Geochemistry Characteristics of Heavy Metal Elements in the Soil and Its Quality Conditions, Pengshan County, Sichuan, China. Chengdu University of Technology, Chengdu.

[3] Li, B.C. (2011) Evaluation on the Soil Environmental Quality and Risk Assessment for the Soil Pollution of Key Regions in Harbin. Northeast Forestry University.

[4] Zhou, Q.X. (2006) New Researching Progresses in Pollution Chemistry of Soil Environment and Chemical Remediation. Environmental Chemistry, 3, 257-265.

[5] Zheng, G.Z. (2007) Theory and Practice of Research of Heavy Metal Pollution in Agricultural Soil. China Environmental Science Press, Beijing, 101-104. 
[6] Xu, Z.Q., Ni, S.J., Zhang, C.J., et al. (2004) Assessment on Heavy Metals in the Sediments of Jinsha River in Panzhihua Area by Pollution Load Index. Sichuan Environment, 3, 64-67.

[7] Guo, Z.H., Xiao, X.Y., Chen, T.B., et al. (2008) Heavy Metal Pollution of Soils and Vegetables from Midstream and Downstream of Xiangjiang River. Acta Geographica Sinica, 1, 3-11.

[8] Zhan, J.Y. (2014) Study on the Basic Condition of Chongqing Farmland and the Main Characteristics of Fertility. Southwest University, Chongqing.

[9] Chinese Ministry of Agriculture (2006) Green Food-Guideline for Area’s Environmental Investigation and Assessment. NY/T 1054-2006. (In Chinese)

[10] Peng, J., Li, Z.Q. and Hou, J.Y. (2007) Application of the Index of Geo-Accumulation Index and Ecological Risk Index to Assess Heavy Metal Pollution in Soils. Guangdong Trace Elements Science, 8, 13-17. 